\title{
DAMPAK PENERAPAN HARGA ACUAN PEMBELIAN (HAP) GULA DI TINGKAT ECERAN TERHADAP HARGA GULA PETANI DAN STABILITAS HARGA GULA
}

\author{
The Impact of Sugar Producer Reference Price at Sugar Auction Price and \\ Price Stability
}

\author{
Yati Nuryati, Bagus Wicaksena, Dwi Wahyuniarti Prabowo \\ Pusat Pengkajian Perdagangan Dalam Negeri, Badan Pengkajian dan Pengembangan Perdagangan, \\ Kementerian Perdagangan RI, JI MI Ridwan Rais No.5 Jakarta Pusat 10110, Indonesia \\ Email: y_nuryati@yahoo.com
}

Naskah diterima: 17/07/2018; Naskah direvisi: 20/10/2018; Disetujui diterbitkan: 08/02/2019

Dipublikasikan online: 31/07/2019

\begin{abstract}
Abstrak
Pemerintah berupaya menjaga stabilitas harga bahan pangan pokok melalui berbagai kebijakan penetapan harga. Salah satunya adalah kebijakan penetapan Harga Acuan Pembelian (HAP) pada komoditas gula. Dalam implementasinya, penerapan HAP Gula di tingkat eceran dinilai berdampak pada penurunan harga gula di tingkat petani/produsen. Kajian ini bertujuan untuk menganalisis pengaruh penerapan HAP Gula terhadap harga lelang gula petani dan stabilitas harga gula, dan merumuskan rekomendasi kebijakan HAP Gula yang efektif. Dengan menggunakan pendekatan analisis ekonometrik melalui Error Correction Model (ECM), hasil analisis menunjukkan bahwa kebijakan HET berpengaruh terhadap harga lelang gula petani dalam jangka pendek. Dalam jangka panjang, harga lelang gula petani lebih ditentukan oleh harga gula impor, stok gula nasional, dan harga lelang gula pada periode sebelumnya. Kebijakan yang berpengaruh signifikan terhadap harga lelang gula yaitu penerapan PPN Gula. Kajian ini merekomendasikan bahwa penetapan kebijakan HAP pada komoditi gula dapat terus dilakukan dalam rangka stabilisasi harga dengan melakukan evaluasi secara berkala. Pemerintah dapat mempertahankan HAP gula sebesar Rp 12.500/kg yang didukung oleh beberapa hal yaitu: menangguhkan penerapan PPN gula petani; mengawasi keberadaan satgas pangan; menerapkan pengawasan pasar gula yang memberikan kepastian pada petani, pabrik gula, dan konsumen.
\end{abstract}

Kata Kunci: Kebijakan HAP, Error Correction Model (ECM), Stabilisasi Harga Gula

\begin{abstract}
The Government strives to keep price stability of staple food through price policy, the so-called "Harga Acuan Pembelian (HAP) for sugar". During its implementation, the policy has given negative impact on farm gate price. This study aims to analyze the effect of HAP for sugar to farm gate price which is reflected in auction price as well as its impact to price stabilization, and formulate effective policy recommendations on HAP for sugar. Using Error Correction Model (ECM), the study shown that HAP for sugar significantly impacted the auction price yet in the short term. While for the long term, the auction price of sugar was more affected by import sugar price, national sugar stock, and sugar auction price in previous period. Moreover, the implementation of value added tax (VAT) on sugar affected significantly to the auction price. The study recommended the HAP for sugar can be consistently implemented with periodic evaluation. Accordingly, the Government can maintain the prevailing HAP at Rp $12.500 / \mathrm{kg}$ which has to be supported by forgoing the VAT policy on sugar; monitoring the role of task force; and strongly supervising the domestic sugar market that is favourable to farmers, sugar millers, and consumers.
\end{abstract}

Keywords: Price Policy, Error Correction Model (ECM), Sugar Price Stabilization

JEL Classification: E31, Q13,Q18 


\section{PENDAHULUAN}

Inflasi bahan makanan terutama pangan pokok di bulan puasa dan Lebaran tahun 2017 mencapai nilai terendah dalam tiga tahun terakhir. Salah satu instrumen kebijakan yang berperan dalam pencapaian tersebut adalah Permendag Nomor 27/MDAG/PER/5/2017 Tentang Penetapan Harga Acuan Pembelian di Petani dan Harga Acuan Penjualan di Konsumen yang didukung dengan pemantauan harga pasar yang intensif. Ketentuan tersebut berlaku untuk beberapa komoditi diantaranya gula, dimana harga acuan pembelian (HAP) konsumen gula ditetapkan sebesar $\mathrm{Rp} 12.500 / \mathrm{kg}$.

Peraturan Menteri Perdagangan Nomor 27/M-DAG/PER/5/2017 tentang Penetapan Harga Acuan Pembelian di Petani dan Harga Acuan Penjualan di Konsumen mulai berlaku pada 16 Mei 2017 untuk sembilan harga komoditas bahan pokok, dimana gula merupakan salah satunya. Permendag ini diterbitkan untuk menjamin ketersediaan, stabilitas, dan kepastian harga beras, jagung, kedelai, gula, minyak goreng, bawang merah, daging sapi, daging ayam ras, dan telur ayam ras. Jika harga di tingkat petani berada di bawah HAP di Petani dan harga di tingkat konsumen berada di atas Harga Acuan Penjualan di Konsumen, maka Menteri Perdagangan (Mendag) dapat menugaskan Badan Usaha Milik Negara (BUMN) untuk melakukan pembelian sesuai ketentuan yang berlaku. Penugasan ini diberikan setelah Mendag berkoordinasi dengan Menteri Pertanian dan Menteri Koordinator Bidang Perekonomian.

Harga Acuan Pembelian di Petani dan Harga Acuan Penjualan di Konsumen berlaku untuk jangka waktu empat bulan terhitung sejak Peraturan Menteri ini diundangkan. Ketentuan ini ditetapkan dengan mempertimbangkan struktur biaya yang wajar, mencakup antara lain biaya produksi, biaya distribusi, keuntungan, dan biaya lain. Permendag Nomor 27 Tahun 2017 ini dinyatakan tetap berlaku walaupun masa berlakunya sudah berakhir selama HAP di Petani dan Harga Acuan Penjualan di Konsumen yang baru belum ditetapkan.

Hasil penelitian sebelumnya menunjukkan bahwa gula merupakan salah satu komoditi yang mempunyai harga yang volatilitas cukup tinggi dibandingkan beras, kedelai dan jagung yang ditunjukkan dengan coefficient of variance (CV) sebesar 11,45\% (Nugraheni, 2014). Harga gula yang 
stabil cukup penting karena harga gula domestik sangat memengaruhi kinerja ekonomi gula secara nasional (Sa'diyah, 2014). variabilitas harga komoditi sering menimbulkan implikasi yang serius terhadap status ketahanan pangan (Akanni, 2013).

Sejalan dengan menjaga agar harga pangan tetap stabil, maka kebijakan harga acuan pembelian (HEP) bisa dikatakan berhasil menstabilkan harga yang tercermin dari data harga gula di tingkat eceran setelah kebijakan tersebut berlaku. Harga gula di tingkat eceran rata-rata secara nasional pada bulan Januari 2017 mencapai Rp $14.628 / \mathrm{kg}$, sedangkan rata-rata harga gula di bulan Mei dan Juni 2017 masingmasing sebesar Rp 13.402/kg dan Rp $13.306 / \mathrm{kg}$. Terjadi penurunan harga sebesar 8,38\% di bulan Mei dan 9,04\% di bulan Juni dibandingkan dengan harga di bulan Januari 2017. Jika dibandingkan dengan harga pada bulan puasa dan lebaran tahun 2016, maka terjadi penurunan harga rata-rata di tahun 2017 sebesar 1,25\% (BPS, 2016 dan BPS, 2017).

Di balik keberhasilan pemerintah dalam menstabilkan harga gula, kebijakan Harga Eceran Tertinggi (HET) dinilai sebagai penyebab rendahnya harga gula di tingkat petani. Asosiasi
Petani Tebu Rakyat Indonesia (APTRI) dalam Harian Rakyat Merdeka tanggal 5 Juni 2017 menyatakan bahwa kebijakan HET Gula sebesar Rp 12.500/Kg disinyalir sebagai penyebab jatuhnya harga gula di tingat petani. Harga gula petani dipasar lelang ditawar lebih rendah yaitu kurang dari $\mathrm{Rp} 10.000 / \mathrm{kg}$ atau dibawah biaya pokok produksi yaitu sebesar Rp 10.600/kg. Pada awal Juni 2017, lelang gula petani di beberapa wilayah pabrik gula (PG) gagal menghasilkan transaksi atau terpaksa dilepas dengan harga yang lebih rendah dari tahun sebelumnya. Dari beberapa lelang, penawaran atau transaksi terjadi pada kisaran Rp 9.500 - Rp10.900/kg atau dengan rata-rata $\mathrm{Rp} 10.383 / \mathrm{kg}$. Sementara itu, rata-rata harga lelang pada tahun 2015 dan 2016 adalah $R p$ 11.000 dan Rp 11.576/kg. Harga lelang gula petani di Pabrik Gula Trangkil sebesar Rp 10.020/Kg dan Pabrik Gula Pati sebesar Rp $9.500 / \mathrm{Kg}$ tidak memberikan keuntungan bagi petani sehingga dilakukan pembatalan lelang.

Susila \& Munadi (2008) melakukan penelitian mengenai keterkaitan harga gula eceran, sistem distribusi dan laju inflasi. Penelitian tersebut menemukan tiga faktor utama yang memengaruhi harga eceran gula di Indonesia, yaitu harga gula impor, harga patokan gula 
petani (HPP), dan biaya distribusi dimana pengaruhnya bersifat inelastis. Setiap kenaikan biaya distribusi sebesar $1 \%$ akan menyebabkan kenaikan inflasi antara $0,001 \%$ sampai $0,003 \%$. Harga gula impor, HPP, dan biaya distribusi dapat menjadi instrumen bagi pemerintah dalam mengendalikan harga di tingkat eceran. Harga gula dunia bersifat elastis terhadap perubahan harga gula domestik (Hairani et. al, 2014)

Pusat Kebijakan Perdagangan Dalam Negeri pada tahun 2015 melakukan analisis lelang gula PTPN/petani dalam rangka stabilisasi harga. Perbedaan antara harga lelang dengan HPP yang besar berpotensi menimbulkan aktivitas perburuan rente. Pada sisi lain, fluktuasi harga lelang di tingkat produsen secara langsung akan berdampak pada stabilisasi harga ditingkat konsumen. Mengingat tuntutan akan transparansi dan akuntabilitas yang semakin kuat, penjualan gula PTPN secara lelang merupakan pilihan terbaik dan teraman pada saat ini. Lelang gula bagi PTPN akan meminimalkan tindakan koruptif dan kolusif, bisa menghasilkan harga tertinggi, dan mendorong penjualan agar berjalan efisien.
Kajian Sistem Stabilisasi Harga Bahan Pokok: Komoditi Gula yang dilakukan oleh Pusat Kebijakan Perdagangan Dalam Negeri pada tahun 2011 menyatakan bahwa dalam menghadapi fenomena lonjakan harga gula diperlukan adanya upaya yang sistematis dan terintegrasi, serta komitmen dan tanggung jawab bersama yang kuat dari berbagai pemangku kepentingan guna menstabilkan harga gula secara efektif antar waktu dan antar wilayah. Untuk mencapai tujuan tersebut, maka kebijakan sistem stabilisasi harga gula yang diperlukan, antara lain: (a) Menetapkan HET di berbagai wilayah sebagai referensi dalam melakukan stabilisasi harga; (b) Memberikan kewenangan khusus kepada Bulog untuk melakukan pengadaan Gula Kristal Putih (GKP) guna membentuk stok gula sebagai Cadangan Gula Pemerintah (CGP), sebagai lembaga yang melakukan stabilisasi harga gula, sebagai IT Gula yang bertindak sebagai pelaku pasar komersial untuk mengkoreksi pasar gula nasional; (c) Impor gula dilakukan berdasarkan neraca gula; dan (d) Meningkatkan sistem pengawasan tata niaga gula, dengan membuat Peraturan Pelaksana Keppres 57/2004 tentang 
penetapan gula sebagai barang dalam pengawasan.

Berdasarkan pada telaah literatur terhadap penelitian-penelitian terdahulu, sedikit sekali bahkan belum ditemukan penelitian yang melihat pengaruh kebijakan di ritel seperti kebijakan HAP terhadap pembentukan harga di tingkat produsen. Untuk mengisi kekosongan gap ini, tulisan ini bertujuan untuk (i) menganalisis Dampak penerapan harga acuan pembelian (HAP) terhadap harga lelang gula petani serta (ii) merumuskan rekomendasi kebijakan mengenai penerapan HAP gula.

\section{METODE}

Berbagai studi menunjukkan bahwa banyak faktor yang membentuk atau menentukan harga gula petani, diantaranya adalah (i) HPP, (ii) stok gula, (iii) harga gula impor, dan (iv) perkiraan atau harapan harga eceran (expected retail price). Penelitian lain menyebutkan faktor-faktor yang memengaruhi harga gula di tingkat konsumen yaitu HPP, biaya distribusi dan harga internasional (susila \& Munadi, 2008) serta faktor nilai tukar dan tarif impor (Rahayuningrum \& Lubis, 2006). Namun, dari faktor-faktor yang memengaruhi harga eceran gula, beberapa penelitian tersebut belum mencakup harga lelang gula petani dan belum menganalisis dampaknya terhadap harga lelang gula petani.

Harga eceran gula juga dipengaruhi oleh harga pokok produksi. Harga pokok produksi yang terus meningkat juga akan meningkatkan harga gula ditingkat eceran. Hasil penelitian sebelumnya menunjukkan bahwa harga pokok pembelian petani (HPP) terhadap harga eceran gula memberikan nilai elastisitas sebesar 0,47\%. Pengaruh HPP terhadap harga eceran inelastis yang menjelaskan bahwa perubahan harga HPP tidak sepenuhnya ditransfer ke harga gula di tingkat eceran dalam negeri (Susila \& Munadi, 2008). Kenaikan harga pokok produksi itu sendiri dikarenakan beberapa komponen biaya naik, antara lain bahan bakar minyak. Sejalan dengan kenaikan harga BBM, biaya transportasi dan upah tenaga kerja meningkat secara signifikan. Menurut hasil penelitian yang sama, struktur biaya tanaman tebu terdiri dari komponen biaya upah sekitar $30 \%$ dan biaya transportasi sekitar $28 \%$. 


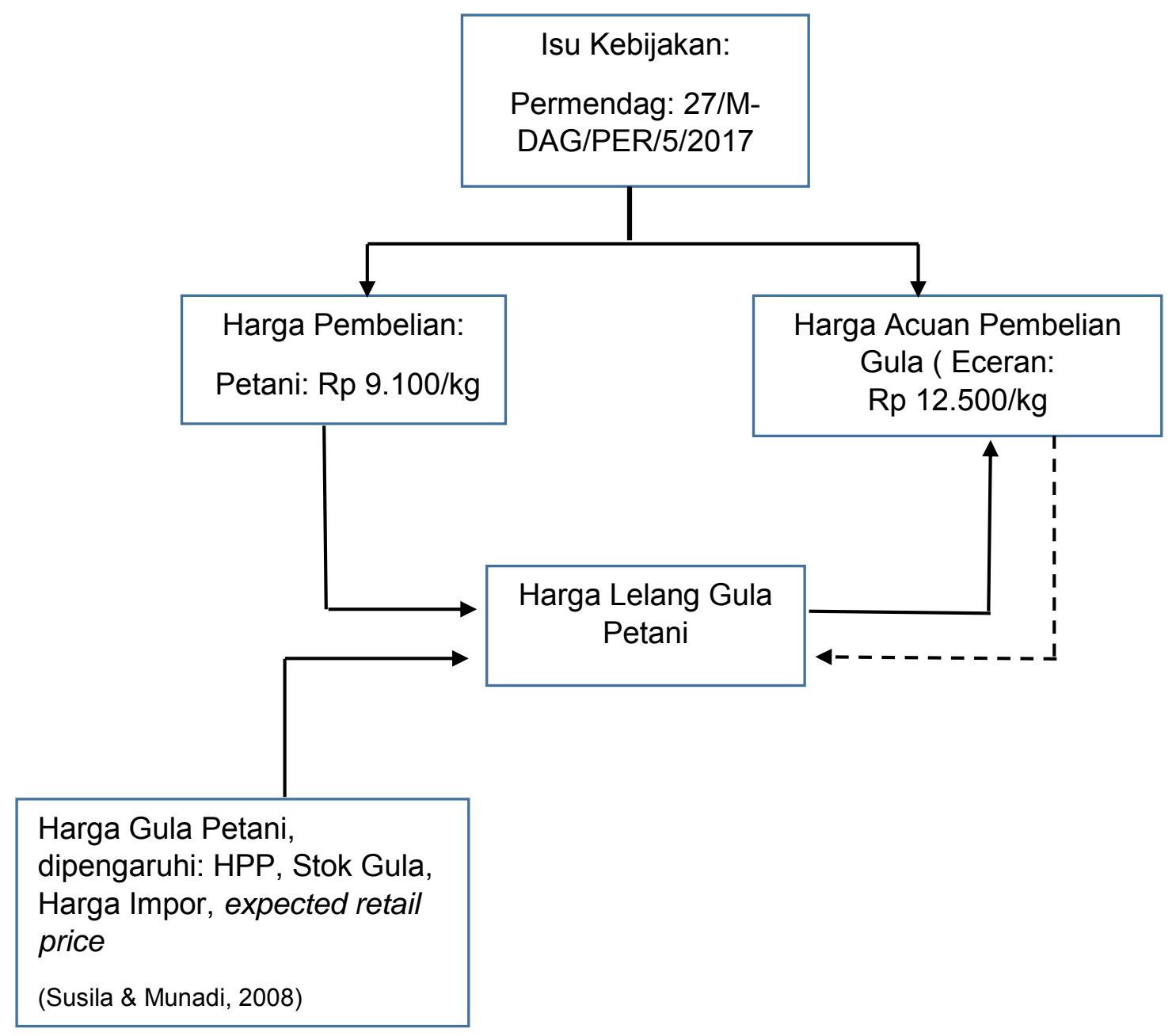

Gambar 1. Kerangka Pemikiran Penelitian

Hasil dari penelitian sebelumnya lebih banyak menjelaskan tentang faktor-faktor yang memengaruhi harga gula di dalam negeri, belum secara spesifik melihat faktor-faktor yang memengaruhi harga lelang gula di petani. Hasil diskusi terbatas dan wawancara dengan stakeholder di lapangan menjelaskan bahwa harga lelang gula di petani dipengaruhi oleh Stok, harga gula impor, kebijakan HET serta isu kebijakan Pajak pertambahan nilai (PPN). Fluktuasi harga lelang gula petani akan memengaruhi harga gula di tingkat eceran dalam negeri. Harga gula impor terhadap harga gula eceran di dalam negeri memengaruhi secara positif meski kurang elastis. Sementara, penelitian sebelumnya melihat dampak stok, kebijakan het dan kebijakan pajak pertambahan nilai (PPN) terhadap harga lelang gula petani. 
Berdasarkan pemikiran tersebut, maka persamaan model yang digunakan untuk menganalisis dampak kebijakan HAP terhadap harga lelang gula petani, secara matematik dapat dijabarkan dengan persamaan berikut:

$\mathrm{HLGt}=\mathrm{C}+\alpha 1 P G D t+\alpha 2 P G I M t+\alpha 3 S T O K t+\alpha 4 D P N t+\alpha 5 P B B M t+\alpha 6 H L G t-$ $1+\varepsilon t$

Dimana:

HLGt : Harga lelang gula pada periode ke $\mathrm{t}$

PGDt :Harga gula eceran domestik (yang diharapkan) pada periode ke $t$

PGIMt : Harga gula impor pada periode ke $\mathrm{t}$

STOKt : Stok gula pada periode ke $\mathrm{t}$

DPNt :Dummy kebijakan PPN pada periode ke $\mathrm{t}$

PBBMt:Harga Bahan bakar minyak pada periode ke $\mathrm{t}$

$\mathrm{HLG}_{\mathrm{t}-1}$ : Harga lelang gula pada periode ke t-1 (lag)

et $\quad$ :galat (Error Term)

Dalam pemodelan, harga eceran gula domestik sampai dengan April 2017 merupakan harapan harga eceran yang diwakili oleh harga eceran sebelumnya, kemudian setelah April 2017 harga eceran yang diharapkan mengacu pada HAP. Selanjutnya harga impor merupakan perhitungan antara harga landed price (harga internasional) yang dikalikan dengan nilai tukar (kurs). Sehingga dalam persamaan, harga internasional dan kurs tidak secara langsung menjadi variabel eksogen. Selanjutnya dalam pengolahan data, variabel HPP tidak dimasukkan karena selama periode analisis HPP nilainya konstan.

\section{Metode Analisis}

Analisis model ekonometrik modern dengan menggunakan data deret waktu (time series) mensyaratkan bahwa data yang digunakan harus stasioner. Persamaan regresi yang menggunakan data yang tidak stasioner menghasilkan nilai dugaan yang bias (spurious regression), sehingga akan menimbulkan kesalahan dalam interpretasi hasil analisis. Untuk mengatasi masalah data (time series) yang tidak stasioner, kajian terdahulu telah menyarankan menggunakan metode koreksi galat (error correction model/ECM) sebagaimana yang telah disarankan oleh Engle \& Granger (1987) dan (Pesaran \& Pesaran, 1997). Tujuan dari metode tersebut adalah membuat galat yang dihasilkan stasioner. Analisis dengan ECM memiliki dua syarat, yaitu 
(1) data tidak stasioner dalam level satu (first different) dan (2) memiliki hubungan kointegrasi jangka panjang.

Dampak penerapan kebijakan HET terhadap harga gula petani dalam penelitian ini menggunakan pendekatan ekonometrik dengan ECM. Engle \& Granger (1987) menjelaskan bahwa jika diantara sejumlah peubah terdapat kointegrasi maka diperoleh kondisi yang dinamakan error-correction representation yang mengindikasikan bahwa perubahan yang terjadi terhadap peubah bebas (dependent variable) tidak hanya dipengaruhi oleh peubahpeubah tidak bebas (explanatory variables) tetapi juga dipengaruhi oleh ketidakseimbangan dari hubungan kointegrasi yang ditunjukkan oleh nilai ECT. Namun kajian ini tidak sampai pada melakukan uji kointegrasi untuk melihat ada atau tidaknya kointegrasi jangka panjang sehingga tidak melakukan tahap pengujian kointegrasi.

Menurut McKay (1998) serta Angelo \& Zapata (2000), dalam ECM ketidakseimbangan jangka pendek diwakili oleh ECT, yang merupakan bentuk lag dari nilai residual pada regresi awal. Regresi awal merupakan regresi dengan menggunakan data yang tidak stasioner, dimana nilai galat ini sudah stasioner. Dengan demikian, ECM akan memperoleh perubah bebas yang memberikan pengaruh jangka panjang dan jangka pendek.

Penjelasanan McKay (1998) serta Angelo \& Zapata (2000) selanjutnya dalam model ECM, ketidakseimbangan jangka pendek diwakili oleh ECT yang merupakan bentuk lag dari nilai residual pada regresi awal. ECM memanfaatkan residual/error dari hubungan jangka panjang untuk menyeimbangkan hubungan jangka pendeknya. Oleh karena itu, persamaan dengan variabel error term sebagai exogenous dinamakan error correction. Persamaan ECM dengan data stasioner untuk menganalisis dampak kebijakan HAP terhadap harga lelang gula petani seperti yang ditunjukkan dalam persamaan (1) disajikan pada persamaan (2) berikut: 
dimana:

$\Delta \mathrm{d} \quad$ :semua variabel stasioner pada level 1

$\varepsilon t-1$ :residual error term yang berperan sebagai exogenus variabel error correction term

\section{Tahapan Analisis}

Sebelum melakukan estimasi dengan menggunakan ECM, semua variabel terlebih dahulu dilakukan uji statistik untuk membersihkan data dari berbagai kendala sehingga data siap diolah dengan beberapa tahapan, sebagai berikut:

\section{a. Uji Akar-Akar Unit (Unit Root Tests)}

Sebuah data time series dikatakan stasioner, jika seluruh moment dari seri tersebut (rata-rata,varians dan kovarians) konstan sepanjang waktu. Pengujian stasioneritas atau akar-akar unit pada semua variabel yang digunakan dalam analisis runtun waktu (time series) perlu dilakukan untuk memenuhi kesahihan analisis ECM. Artinya bahwa data yang digunakan harus bersifat stasioner. Dalam pengertian bahwa perilaku data yang stasioner memiliki varians yang tidak terlalu besar dan mempunyai kecenderungan untuk mendekati nilai rata-ratanya. Pengujian unit root pada semua variabel yang akan dianalisis di dasarkan pada Augmented Dickey Fuller Test (ADF) yang perhitungannya menggunakan bantuan software komputer E-views 9.0.

Setelah melakukan uji stasioneritas (uji unit-root) dengan menggunakan Augmented Dickey Fuller test (ADF) semua variabel yang dianalisis stasioner pada level 1. Selain uji stasioneritas, semua variabel juga dilakukan pengujian multikolinearitas untuk melihat terdapat ada tidaknya korelasi antar variabel. Setelah dilakukan pengujian terhadap multikolinearitas, hasil pengujian menunjukkan bahwa semua variabel tidak terdapat multikolinearitas yang ditunjukkan dengan nilai $r$ kurang dari 0,75.

\section{b. Estimasi Model.}

Setelah dilakukan pengujian unit root dan multikolinearitas, selanjutnya tahap estimasi model. Sesuai tujuan yang telah disebutkan, penelitian ini untuk menganalisis dampak penerapan HAP terhadap harga lelang gula petani. Estimasi dilakukan dengan beberapa tahapan, yaitu tahapan estimasi dengan menggunakan regresi linear serta estimasi dengan model ECM. Estimasi model ECM dilakukan dengan bantuan perangkat sofware komputer program Eviews 9.0. 


\section{Data dan Sumber data}

Penelitian ini menggunakan data sekunder periode mingguan mulai tahun 2016-2017, terdiri dari harga Eceran gula di dalam negeri (PGD), Harga pembelian pemerintah (HPP), stok gula (Stok), harga lelang petani (HLG), harga impor (PGIM), kurs, harga BBM (BBM) serta kebijakan PPN. Data sekunder diperoleh dari BPS, Direktorat Jenderal Perdagangan Dalam Negeri (Kementerian Perdagangan), Kemenko Perekonomian, Asosiasi Gula Indonesia (AGI), Ditjenbun Kementerian Pertanian, London-LIFFE; Bloomberg, CEIC serta sumber referensi lainnya yang terkait. Data primer juga digunakan untuk mendapatkan informasi secara praktis di lapangan terkait dengan pelaksaan lelang gula petani, yaitu di Surabaya serta untuk menjustifikasi faktor-faktor yang tidak dapat tercakup dalam model persamaan.

\section{HASIL DAN PEMBAHASAN}

Penerapan Harga Acuan Pembelian (sesuai dengan Permendag No 27/2017).

Kebijakan HAP merupakan salah satu upaya untuk menjaga stabilitas harga gula, terutama menjelang puasa dan hari raya idul fitri. Selain tujuan tersebut, HAP juga diterapkan untuk mengurangi tindakan spekulasi harga serta mafia dari margin keuntungan yang lebih tinggi yang dapat merugikan konsumen. Pada mulanya, kebijakan HAP sebagaimana yang tercantum dalam Peraturan Menteri Perdagangan, yaitu Permendag No 27/MDAG/PER/5/2017 yang direvisi menjadi Permendag No 58/M-DAG/PER/5/2018 bertujuan memberikan harga acuan terhadap pembelian di tingkat petani dan harga acuan penjualan di konsumen yang dilakukan oleh perum Bulog. Dalam pelaksanaannya, pembelian dan penjualan terhadap komoditi yang tercantum pada peraturan tersebut juga dapat dilakukan oleh BUMN lainya dapat bekerja sama dengan BUMN dan BUMD, koperasi dan/atau swasta.

HPP merupakan salah satu instrumen untuk mendorong petani tetap menanam tebu dengan adanya jaminan harga terutama pada saat masa puncak produksi sehingga dapat menjaga stabilitas harga di tingkat pasar lelang gula milik petani tebu. Stabilitas harga di pasar lelang gula milik petani salah satunya dapat dilakukan melalui pembentukan lembaga yang dapat dijadikan instrumen dan ditetapkan dengan Keputusan Pemerintah. Lembaga ini harus membeli gula petani pada saat harga dibawah HPP artinya membeli dengan harga yang lebih mahal 
dari yang seharusnya (Cahyaningsih, 2015).

Sebaliknya, HAP merupakan batas pengaman dari sisi konsumen. Harga acuan pembelian gula ini dapat digunakan sebagai salah satu acuan dalam melakukan stabilisasi harga. Artinya, apabila harga gula di pasar melebihi HAP, pemerintah dapat langsung melakukan stabilisasi harga dengan menggunakan berbagai instrumen kebijakan (Pusat Kebijakan Perdagangan Dalam Negeri, 2015). Volatilitas harga pangan secara umum juga tengah menjadi perhatian bagi pengambil kebijakan di negara-negara berkembang sehingga intervensi pemerintah ke pasar komoditi pangan kembali menjadi populer (kornher, 2013). Adapun instrumen yang dapat digunakan dalam menjaga ketidakstabilan harga dapat dikelola dengan beberapa pendekatan antara lain melalui intervensi publik dengan penetapan harga atap (harga tertinggi) di pasar yang didukung dengan upaya penyiapan pasokan (Galtier, 2013).

HAP juga merupakan acuan bagi harga tebu di tingkat petani sehingga dapat terus termotivasi untuk meningkatkan produksi dalam mendukung capaian swasembada gula. Peningkatan produksi salah satunya dapat dilakukan melalui peningkatan rendemen tebu. Yunitasari et.al (2015) menjelaskan bahwa peningkatan produksi gula dapat dilakukan melalui peningkatan rendeman, perluasan areal serta produktivitas tebu dan lebih lanjut komponen-komponen ini akan menjadi pendorong capaian peningkatan produksi untuk swasembada gula nasional.

\section{Perkembangan HPP, Harga Lelang Gula, Harga Eceran, HET}

Kebijakan HAP gula merupakan salah satu instrumen yang diperlukan dalam mengendalikan harga gula di pasar domestik. Jika mengacu pada perkembangan harga gula yang terdiri dari harga di tingkat produsen yang didukung dengan kebijakan harga patokan petani serta harga di tingkat eceran, maka dapat dilihat bahwa pergerakan harga gula cenderung meningkat setiap tahunnya.

Selama periode Bulan Januari 2010 hingga Juni 2017, harga lelang relatif stabil dengan kenaikan sekitar 0,35\%. Kenaikan tersebut tidak jauh berbeda dengan HPP yang mencapai $0,04 \%$ pada periode yang sama. Dengan demikian, dapat diinterpretasikan bahwa kenaikan HPP akan diikuti oleh kenaikan harga di tingkat produsen/petani dalam bentuk 
harga lelang. Demikian juga dengan kenaikan harga di tingkat eceran yang sebesar $0,34 \%$ pada periode yang sama.

Namun jika dilihat dalam tiga tahun terakhir, kenaikan harga gula di tingkat eceran jauh lebih besar dibandingkan dengan kenaikan HPP dan harga lelang petani. Selama periode Juni 2014 hingga Juni 2017, HPP hanya naik sekitar $0,20 \%$ dan diikuti oleh kenaikan harga lelang sebesar $1,01 \%$ yang berdampak pada kenaikan harga di tingkat konsumen sebesar $0,76 \%$. Pada periode yang sama, harga gula di tingkat eceran rata-rata sekitar $\mathrm{Rp}$ 13.200/Kg, sementara HPP dan harga lelang masing-masing sebesar $\mathrm{Rp}$ $8.900 / \mathrm{Kg}$ dan $\mathrm{Rp} 10.350 / \mathrm{Kg}$. Untuk tingkat eceran, harga pada kisaran tersebut relatif tinggi dibandingkan dengan rata-rata harga gula di pasar internasional yang dihitung dari harga paritas Gula Kristal Putih sebesar Rp $12.500 / \mathrm{Kg}$. Atas dasar tersebut, didukung dengan arah kebijakan Pemerintah dalam menjaga tingkat inflasi, maka diberlakukan kebijakan HAP Gula Pasir sebesar Rp 12.500/Kg sejak Bulan Mei 2017. Dalam perkembangannya, kebijakan HAP dapat menekan harga gula di tingkat eceran sekitar $8,38 \%$ sejak diberlakukan.

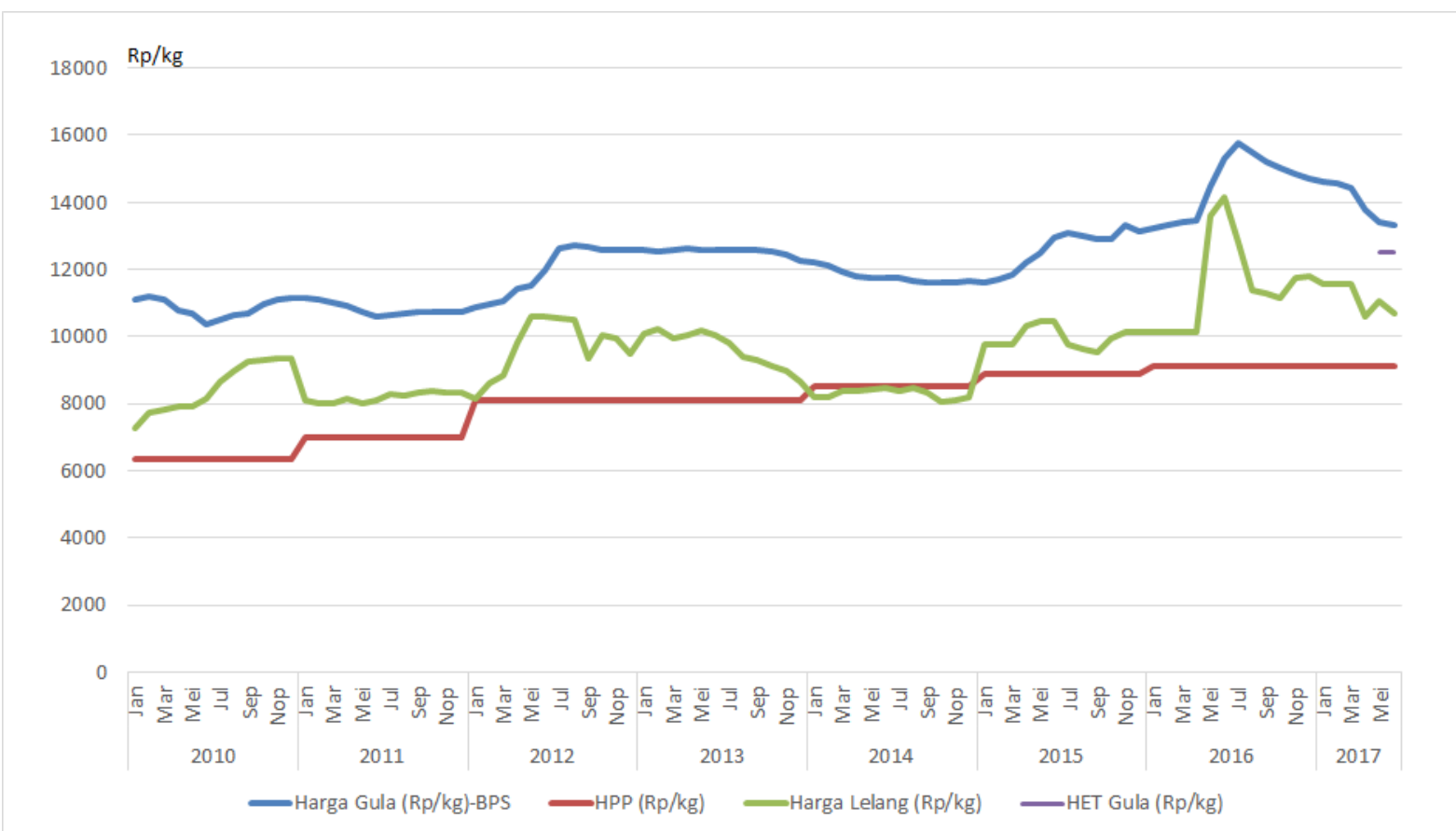

Gambar 2. Perkembangan Harga HPP, Lelang Gula Tebu, Harga Eceran dan HET gula Sumber: BPS, SP2KP Ditjen PDN, DGI-Ditjen Perkebunan Kementerian Pertanian (2017), diolah 
Perkembangan Harga dan Kebijakan Harga Produsen

Harga gula di dalam negeri tidak terlepas dari kebijakan pergulaan nasional, khususnya kebijakan yang berdampak pada harga gula. Secara umum, Susila dan Sinaga (2005) menjelaskan bahwa perkembangan harga gula, terutama harga di tingkat eceran, tidak murni mengikuti hukum penawaran dan permintaan. Sebelum liberalisasi perdagangan tahun 1998, harga gula di tingkat petani ditentukan oleh pemerintah melalui Bulog yang dikenal sebagai harga provenue. Analisis harga dalam studi dimaksud menunjukkan bahwa dalam menentukan besaran harga provenue, pemerintah mempertimbangakan target harga eceran yang ingin dicapai, inflasi secara kumulatif sebagai representasi biaya produksi dan transpor, serta harga pupuk yang juga mewakili biaya produksi. Ketiga variabel tersebut berkorelasi positif terhadap harga provenue. Dengan perkataan lain, kenaikan biaya produksi dan transpor merupakan dua pertimbangan dalam menentukan harga provenue, di samping harga eceran. Sebagai contoh, jika inflasi meningkat sebesar 1\%, maka harga tingkat petani meningkat sekitar $0.84 \%$. Selanjutnya, jika harga pupuk naik sebesar $1 \%$, maka harga tingkat petani juga meningkat sekitar $0.60 \%$.

Pada tahun 1998-2002, pemerintah melepas harga gula petani pada mekanisme pasar bebas. Walaupun ada upaya menetapkan harga provenue seperti yang terjadi tahun 1999-2000, kebijakan tersebut tidak lagi efektif karena mekanisme harga yang terjadi sudah mengikuti perdagangan bebas. Hal ini terjadi karena Bulog tidak lagi mempunyai wewenang tunggal, baik dalam hal impor maupun pembelian gula petani. Dengan demikian, pada periode regim kebijakan liberalisasi ini, harga gula lebih banyak ditentukan oleh mekanisme pasar bebas yang mengacu pada harga gula di pasar internasional.

Kebijakan tata niaga impor gula pada bulan September 2002 mengubah secara fundamental pembentukan harga di tingkat petani yang merupakan awal Regim Kebijakan Terkendali. Salah satu esensi dasar kebijakan ini yang berkaitan dengan harga gula tingkat petani ádalah bahwa impor gula boleh dilakukan bila harga di tingkat petani (HPP) minimal Rp 3.410/kg. Kebijakan ini pada dasarnya menjamin bahwa harga di tingkat petani minimal $\mathrm{Rp} 3.410 / \mathrm{kg}$ berdasarkan kebijakan pada saat itu. 
Dengan mekanisme tersebut, HPP selama setahun terakhir meningkat sejalan dengan peningkatan biaya produksi. Pada tahun 2005 sebagai contoh, HPP ditetapkan sebesar Rp $3.800 / \mathrm{kg}$. Harga gula di pasar internasional terus melonjak dan awal tahun 2006 sudah diatas USD 450/ton. Petani melalui APTRI juga mendesak kenaikan HPP untuk mengimbangi kenaikan harga gula di pasar internasional, serta kenaikan harga BBM diatas $100 \%$ pada tahun 2005 yang meningkatkan biaya produksi hampir sebesar 30\%. Ditambah dengan harga sewa lahan yang terus meningkat sekitar $10 \%$ per tahun, kenaikan upah, dan kenaikan biaya distribusi, biaya pokok produksi terus meningkat sehingga memberi tekanan pada kenaikan HPP. Pada tahun 2015, HPP ditetapkan sebesar Rp 8.900/kg. Namun setelah tahun 2015, kenaikan HPP relatif konstan mengikuti perkembangan harga internasional serta produktivitas on-farm dan industri pengolah tebu yang diindikasikan dengan rendemen. Sebagai catatan, jika terjadi perbaikan rendemen, maka HPP akan dinaikkan sebagai insentif bagi produsen. Saat ini, HPP ditetapkan Rp 9.100/Kg.

Dalam menjamin harga minimal tersebut, tiga pelaku bisnis yaitu asoisiasi petani, pabrik gula (PG), dan investor yang umumnya terdiri dari pedagang besar melakukan kerja sama. Investor dapat berperan sebagai pemberi dana talangan senilai produksi gula petani dikalikan dengan harga minimum yang ditetapkan pemerintah yang mengacu kepada HPP. Dana talangan tersebut diberikan petani ketika petani menyerahkan tebunya ke PG untuk diolah. Setelah diproses menjadi gula dan dilelang, maka digunakan pendekatan bagi hasil. Jika harga lelang jatuh dibawah HPP, maka petani hanya menerima harga senilai HPP, resiko kerugian ditanggung investor. Jika harga lelang lebih tinggi dari HPP, maka 50\%-60\% dari kelebihan tersebut menjadi bagian petani, sedangkan sisanya menjadi milik investor.

Selama 2007-2017 perbedaan antara HPP dan harga lelang gula petani stabil pada kisaran 17,0\%. Artinya, dalam jangka pendek, dengan margin pemasaran yang sama, harga lelang gula petani akan mengikuti HPP. Semakin tinggi HPP, semakin kuat dorongan untuk meningkatkan harga lelang gula petani. Namun untuk tahun 2017, HPP sama dengan HPP tahun 2016 sebesar Rp 9.100 per kg. Dengan demikian, HPP dinilai tidak berperan 
terhadap penurunan harga lelang gula saat ini karena HPP tidak ada perubahan. Oleh karena itu, variabel HPP pada analisis selanjutnya tidak digunakan dan dikeluarkan dari model persamaan.

\section{Estimasi Dampak Penerapan HET terhadap Harga Lelang Gula.}

Hasil estimasi model persamaan linear dengan periode tahun 2016-2017 (mingguan s.d Agustus) menunjukkan bahwa estimasi terhadap model tersebut memiliki nilai $\mathrm{R}^{2}$ disesuaikan sebesar 0,71 yang menunjukkan bahwa semua variabel bebas yang diduga sebagai faktor-faktor yang memengaruhi harga lelang gula dapat menjelaskan model dengan baik sebesar $71 \%$ variasi dari harga lelang gula. Nilai Durbin-Watson sebesar 2,02 menunjukkan bahwa tidak terdapat masalah autokorelasi dalam persamaan model harga lelang gula tersebut. Pada model persamaan dengan variabel level (0) menunjukkan bahwa kebijakan HAP dapat menurunkan harga lelang di tingkat petani, namun secara statistik tidak signifikan (Tabel 1).

Tabel 1. Hasil Estimasi Persamaan Jangka Pendek Dampak Penerapan HAP Terhadap Harga Lelang Gula Petani (Parameter Estimasi)

\begin{tabular}{lccc}
\hline \multicolumn{1}{c}{ Variabel } & Coefficient & t-statistik & Probabilitas \\
\hline Intersep & $3.277,33$ & 0,7429 & 0,4599 \\
Lag Harga Gula Domestik(PGD(-1)) & $-0,1536$ & $-1,2875$ & 0,2019 \\
Harga Gula Impor (PGIM) & $0,7040^{* * *}$ & 2,8108 & 0,0063 \\
STOK & $0,0017^{* * *}$ & $-3,3913$ & 0,0011 \\
Dummy PPN(DPN) & $-53,1166^{* * *}$ & $-2,7087$ & 0,0084 \\
Harga BBM (PBBM) & 0,1543 & 0,2759 & 0,7834 \\
Lag Harga Lelang Gula (HLG(-1) & $0,5078^{* * *}$ & 4,9442 & 0,0000 \\
$\quad * * *$ : Berbeda nyata pada taraf alpha 1\% & & & \\
R-Squared & 0,7097 & Durbin-Watson Stat : 2,0209 \\
Adjusted R-Squared & 0,6865 & Prob (F-statistic): 0,0000 \\
\hline
\end{tabular}

Sumber: Hasil Olahan Data Sekunder

Tabel 1 tidak menjelaskan secara rinci faktor-faktor yang memengaruhi harga lelang gula ditingkat petani karena estimasi ini berasal dari persamaan regresi dengan variabel yang non-stasioner. Namun demikian, hasil estimasi ini menjadi acuan dalam melangkah pada hasil estimasi persamaan error correction model $(E C M)$ dengan variabel yang stasioner. 
Tabel 2. Hasil Estimasi Error Correction Model (ECM) Dampak Penerapan HET terhadap Harga Lelang Gula Petani

\begin{tabular}{lccc}
\hline & Coefficient & t-statistik & Probabilitas \\
\hline Intersep & $-32,0879$ & $-0,3782$ & 0,7064 \\
Lag Harga Gula Domestik(PGD(-1)) & $0,2709^{*}$ & 1,2093 & 0,1304 \\
Harga Gula Impor (PGIM) & $0,7640^{* *}$ & 2,0715 & 0,0418 \\
DSTOK & $-0,0017^{* *}$ & $-2,0198$ & 0,0471 \\
Dummy PPN(DPN) & 5,0225 & 0,3407 & 0,7343 \\
Harga BBM (PBBM) & 0,7260 & 0,6006 & 0,5499 \\
Lag Harga Lelang Gula (HLG(-1) & $0,3353^{*}$ & 1,7348 & 0,0870 \\
ECM & $-0,9351^{* * *}$ & $-4,0438$ & 0,0001 \\
$\quad * * *$ : Berbeda nyata pada taraf alpha 1\% & & & \\
$\quad * *$ : Berbeda nyata pada taraf alpha 5\% & & & \\
$\quad *$ : Berbeda nyata pada taraf alpha 10\% & & & \\
$\quad$ R-Squared & 0,2878 & Durbin-Watson Stat : 2,0953 \\
Adjusted R-Squared & 0,2195 & Prob (F-statistic): 0,0006 \\
\hline
\end{tabular}

Sumber: Hasil Olahan Data Sekunder

Harga gula domestik (PGD) yang merupakan Harga eceran yang diharapkan (Expected real price) dalam jangka pendek (selama periode analisis) berdampak pada penurunan harga lelang namun secara tidak langsung. Dalam jangka panjang yang ditunjukkan dengan persamaan ECM (Tabel 2), harga eceran yang diharapkan mempunyai pengaruh positif terhadap harga lelang gula dan signifikan pada taraf nyata $10 \%$. Artinya HAP mempunyai pengaruh terhadap harga lelang meski secara tidak langsung. Secara statistik kecilnya signifikansi variabel ini dikarenakan periode data yang digunakan masih relatif pendek dengan periode mingguan dimana penerapan harga eceran tertinggi gula mulai diberlakukan per Mei 2017.

Sejalan dengan hasil analisis ekonometrik di atas, fakta dilapangan memberikan indikasi bahwa harga eceran tertinggi gula yang ditetapkan oleh Pemerintah (berdasarkan Permendag 58/M-DAG/PER/5/2018) sebesar Rp 12.500/kg memiliki pengaruh terhadap harga lelang gula di tingkat petani. Harga lelang gula yang terjadi sejak Juni 2017 lebih rendah dan menyebabkan terjadi gagal lelang karena penawaran yang lebih rendah. Pemerintah menetapkan harga HAP pada gula sebesar $\operatorname{Rp} 12.500 / \mathrm{kg}$ untuk menjaga stabilitas harga gula di tingkat konsumen. Namun, sejalan dengan 
penerapan HAP, hasil informasi di lapangan terdapat isu lain yaitu penerapan PPn pada komoditi gula. Isu ini cukup memberi tekanan kepada petani gula, karena penerapan PPn memberikan kekhawatiran kepada para pedagang dimana PPn merupakan pajak terhutang yang akan dibayarkan diakhir tahun. Isu ini pada akhirnya membuat pedagang menekan harga gula di tingkat petani. Hal ini ditunjukkan juga dalam hasil estimasi selama periode analisis, isu penerapan PPn berpengaruh negatif terhadap harga lelang gula. Harga gula domestik itu sendiri dipengaruhi oleh harga gula impor, harga patokan gula petani (HPP), dan biaya distribusi namun pengaruhnya inelastis. Sehingga ketiga variabel ini dapat digunakan sebagai instrumen dalam mengendalikan harga di tingkat eceran (Susila \& Munadi, 2008).

Isu lain dari pegamatan dilapangan menunjukkan bahwa sejalan dengan rendahnya harga lelang gula petani adalah merembesnya gula kristal rafinasi (GKR) ke pasar konsumen sehingga stok GKP berlimpah dan berdampak pada berlimpahnya stok GKP saat musim giling. Tingginya stok GKP di awal musim giling disebabkan karena adanya perubahan konsumsi
GKP seiring dengan perubahan pola konsumsi masyarakat (Haryana \& Wicaksena, 2016). Meski demikian pemerintah telah berupaya untuk meminimalisir rembesan GKR melalui pasar lelang komoditas (Wicaksena, 2017).

Hasil penelitian Ernawati \& Erna (2013) menunjukkan bahwa gula dalam negeri juga sangat dipengaruhi oleh produktivitas (kapasitas produksi/giling) dan rendeman. Peningkatan rendemen dan kapasitas produksi mampu meningkatkan produksi gula hingga $5 \%$, menurunkan impor hingga $17 \%$ serta menurunkan harga gula di dalam negeri sebesar $1 \%$.

Harga gula impor terhadap harga lelang menunjukkan nilai yang positif dan secara statistik signifikan. Hal ini menunjukkan bahwa pasar gula di Indonesia terintegrasi dengan pasar internasional. Dengan menghitung elastisitas, Jika terjadi perubahan harga gula dipasar internasional sebesar 1\% akan menyebabkan perubahan harga lelang sebesar 0,43\%. Hal ini memberi indikasi bahwa penawaran yang dilakukan oleh peserta lelang masih sangat memperhitungkan perkembangan harga di pasar internasional. Hasil penelitian sebelumnya juga menunjukkan terdapat 
hubungan yang positif antara harga gula impor dengan harga gula ditingkat eceran di dalam negeri meski dengan nilai elastisitas yang berbeda. Susila \& Sinaga (2005) menghasilkan nilai elastisitas harga gula impor sebesar 0,32\%. Sedangkan Susila dan Munadi (2008) menghasilkan nilai elastisitas harga gula impor sebesar $0,27 \%$ terhadap harga gula di tingkat eceran dalam negeri.

Penurunan harga gula impor yang terjadi beberapa bulan terakhir telah memberikan indikasi pada penurunan daya saing industri gula di dalam negeri. Isu rembesan Gula Kristal Rafinasi (GKR) juga menyebabkan gula petani dan PTPN menjadi tidak laku di pasaran dan berpotensi menekan harga gula di tingkat petani hingga $\mathrm{Rp} 8.600 / \mathrm{kg}$ (Survey, Agustus 2017). Selain itu pedagang tidak dapat menjual gula tebu petani di jangkauan pasar yang lebih luas karena Impor gula rafinasi sudah masuk ke pasar dalam negeri dan bahkan telah merembes ke pasar konsumen.

Fakta dilapangan, kondisi ini juga merupakan salah satu penyebab rendahnya harga lelang gula petani. Meski harga gula petani masih dipengaruhi oleh harga gula impor melalui harga gula di pasar internasional dan nilai tukar rupiah, namun pengaruh harga gula internasional terhadap harga gula petani tidaklah sekuat pengaruh HPP. Kondisi nilai tukar yang relatif stabil, namun harga gula impor cenderung menurun pada periode awal 2017 yang disebabkan penurunan harga gula di pasar internasional sejak Oktober 2016. Pada Oktober 2016, harga gula dunia yang secara komposit mencapai USD 490 per ton, menurun menjadi USD 350 per ton pada Mei 2017, atau mengalami penurunan sebesar $28,6 \%$ selama periode tersebut. 


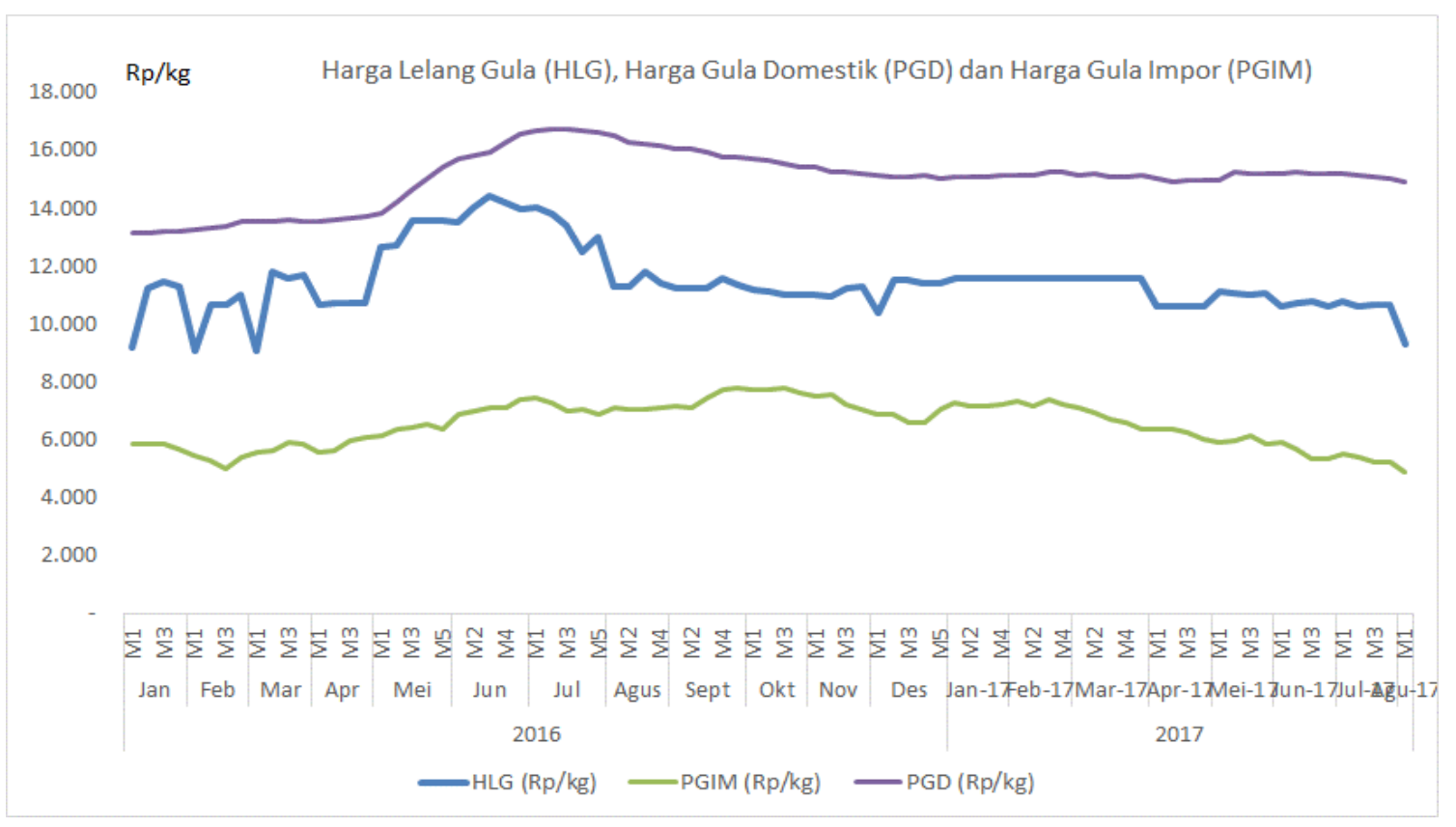

\section{Gambar 3. Harga Lelang Gula, Harga Gula Domestik dan Harga Gula Impor}

Sumber: BPS, DGI-Ditjenbun Kementan, dan Chicago Board of Trade (СВOT) (2017), diolah

Keterangan: Harga gula impor merupakan harga gula internasional (CIF) yang telah dikalkulasi dengan kurs rupiah

Variabel stok terhadap harga lelang gula petani bertanda negatif dan secara statistik signifikan. Hal ini berarti bahwa kecukupan stok gula akan memengaruhi pada pembentukan harga lelang gula. Setiap ada kenaikan stok gula sebesar $1 \%$, akan menurunkan harga lelang sebesar $0,007 \%$ atau sebaliknya. Stok ini juga merupakan salah satu indikasi terhadap tinggi atau rendahnya harga lelang gula di tingkat petani, meski respon stok terhadap harga lelang gula relatif sangat kecil namun cukup signifikan. Pada kondisi ini, stok gula sedang menurun. Berdasarkan perkiraan neraca gula tahun 2017, stok gula terus menurun dari 862.705 ton pada Januari 2017 menjadi hanya sekitar 13.943 ton pada Juni 2017 (Laporan DGI, April 2017). Situasi ini seharusya mendorong kenaikan harga lelang gula petani, bukan sebaliknya justru menekan harga. Dalam struktur industri gula, dari level produsen, industri gula cenderung oligopoli dimana terdapat beberapa perusahaan besar seperti PT. Sugar Group serta perusahaan BUMNnya, di level distributor memiliki struktur (oligopoli), serta di level sub distributor dan grosir retailer merupakan struktur pasar dengan beberapa pelaku usaha 
terkait) (KPPU, 2010). Dengan demikian, keberadaan stok gula tentunya hanya akan dikuasai oleh beberapa pelaku/pedagang. Banyaknya volume stok gula menjadi bahan pertimbangan dalam penentuan besarnya harga lelang gula yang pada akhirnya berdampak pada pembentukan harga eceran.

Kecilnya respon variabel stok terhadap penurunan harga lelang gula dikarenakan terdapat faktor lain seperti kebijakan HAP gula, isu penerapan PPn serta gula impor. Isu lain yang mengemuka selama periode analisis yaitu keberadaan Satgas Pangan yang dibentuk oleh Kepolisian Republik Indonesia bersama sejumlah kementerian terkait untuk menjamin stabilisasi harga menjelang Bulan Ramadhan dan Hari Raya Idul Fitri tahun 2017.

Dalam menjalankan fungsinya, Satgas Pangan berkewajiban melakukan pengawasan harga pangan, termasuk gula, di pasar rakyat dan akan dievaluasi setiap 2 (dua) minggu. Selain itu, Satgas pangan juga memiliki

\footnotetext{
https://regional.kompas.com/read/2018/03/24/09 165321/selama-2017-satgas-pangan-tangani-407kasus-kebanyakan-dari-jawa-dan

https://www.republika.co.id/berita/nasional/daera
}

mandat untuk memantau ketersediaan pangan pokok serta penegakan hukum bagi pelaku yang terbukti melakukan moral hazard yang berdampak pada naiknya harga pangan, termasuk gula. Pada tingkat teknis di daerah, Satgas Pangan dibentuk oleh Polisi Daerah bekerja sama dengan Dinas terkait yang mengacu pada keputusan di tingkat pusat.

Selama tahun 2017, setidaknya terdapat 407 kasus yang ditangani dimana sebagian besar terkait dengan tindakan spekulasi oleh oknum spekulan untuk komoditas beras dan gula1. Khusus untuk komoditas gula, salah satu kasus yang berhasil ditangani adalah pengamanan gula di Jawa Tengah sebanyak 35 ton yang tidak memiliki Standard Nasional Indonesia $(\mathrm{SNI})^{2}$. Keberadaan Satgas Pangan secara konsisten disosialisasikan di beberapa daerah, termasuk Jawa Timur yang merupakan daerah penghasil bahan pokok termasuk gula ${ }^{3}$. Selama periode analisis, keberadaan Satgas Pangan dipersepsikan oleh stakeholder gula,

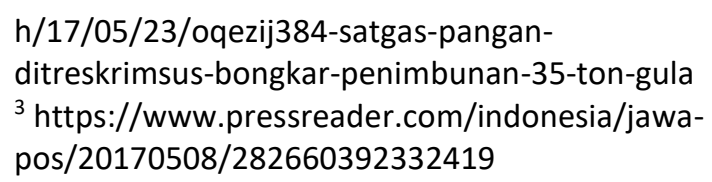


terutama pedagang, sebagai langkah antisipatif yang juga berpotensi menimbulkan negative excess. Dalam hal ini, para pedagang sulit dan khawatir untuk melakukan pembelian barang, termasuk komoditi gula yang dapat dijadikan stok.

Negative excess penindakan moral hazard yang berpotensi dilakukan oleh pedagang merupakan hal yang problematis. Rahman (2015) menjelaskan dalam perspektif hukum bahwa tindakan aparat hukum dalam mengantisipasi penimbunan pangan memiliki kelemahan dalam hal ketentuan teknis penimbunan, instansi yang relevan, serta motif pelaku penimbunan yang belum tentu memenuhi kaidah moral hazard. Beberapa hal tersebut pada akhirnya cukup relevan jika dikaitkan dengan kondisi selama periode analisis dimana pelaku usaha memiliki kekhawatiran dalam mengelola stok gula.

Harga lelang dengan lag (-1) atau dengan nama variabel HLG(-1) merupakan harga lelang pada periode $(\mathrm{t}$ ) yang dipengaruhi juga oleh harga lelang pada periode sebelumnya ( $\mathrm{t}-1)$. Situasi ini mencerminkan bahwa pembentukan harga lelang melalui proses penyesuaian (adjusment process), artinya penawaran harga yang dilakukan oleh peserta lelang pada periode ( $\mathrm{t}$ ) tetap mempertimbangkan harga lelang sebelumnya. Pada sisi lain, tingginya harga lelang akan berdampak pada pembentukan harga di tingkat eceran yang relatif tinggi. Namun demikian, Penjualan secara lelang dapat memberikan beberapa manfaat bagi produsen gula, diantaranya untuk mendorong penciptaan harga transparan, kompetitif, inklusif serta proses penjualan yang efisien (Puska Dagri, 2015).

Dari hasil estimasi persamaan ECM tersebut menunjukkan bahwa dalam jangka pendek (selama periode analisis) kebijakan HAP mempunyai pengaruh terhadap penurunan harga lelang gula namun secara tidak langsung. Demikian juga dengan adanya isu kebijakan PPN. Dalam jangka panjang, harga lelang gula petani lebih ditentukan oleh stok, harga impor dan harga lelang gula pada periode sebelumnya. Pengaruh ini terjadi baik dalam jangka pendek maupun jangka panjang. Meski hasil temuan dilapangan menunjukkan bahwa pada periode analisis, harga lelang yang rendah menyebabkan banyak lelang gula yang tidak dilaksanakan karena harga yang terjadi di pasar lelang lebih rendah dari harga 
perkiraan sementara (HPS). Harga lelang yang ditawarkan pada saat periode survey yaitu kisaran $R p$ $9.300 / \mathrm{kg}$ - Rp 9.425/kg. Padahal harga lelang merupakan penentu awal terbentuknya harga gula di tingkat eceran. Dengan penetapan harga di tingkat eceran sebesar Rp 12.500/kg, peserta lelang (D1) sudah menurunkan margin yang selama ini mereka terima yaitu dari $27,7 \%$ menjadi sekitar $20,4 \%$ dari HAP atau setara Rp $9.038 / \mathrm{kg}$. Sementara penawaran yang dilakukan D1 di beberapa pabrik gula (PG) pada awal Juni 2017 (yaitu sebesar Rp $10.383 / \mathrm{kg}$ ) sudah lebih tinggi dari yang biasa mereka lakukan.

Penetapan HAP sebesar Rp12.500/kg turut memberi tekanan pada harga lelang gula petani, namun dalam jangka pendek. Harga eceran yang diharapkan oleh distributor besar (D1) yang selanjutnya ditransmisikan ke agen/D2 dan pengecer juga menentukan harga gula petani. Sebelum ditetapkan HAP, D1 sebenarnya adalah pembentuk harga yang akan diikuti oleh para agen dan pengecer. Dalam jangka panjang, dengan adanya HAP sebesar Rp $12.500 / \mathrm{kg}$, D1 tidak lagi leluasa menentukan harga ecerean. Para D1 akan menggunakan HAP untuk menentukan perkiraan harga lelang gula petani setelah memperhatikan margin dan keuntungan di semua lini distribusi.

\section{KESIMPULAN DAN REKOMENDASI KEBIJAKAN}

Faktor-faktor yang menentukan harga lelang gula di tingkat petani yaitu harga gula impor, stok gula dan harga lelang gula pada periode sebelumnya. Namun demikian, stok gula mempunyai pengaruh sangat kecil terhadap penurunan harga lelang gula. Kebijakan HAP dan isu kebijakan penerapan PPN memiliki pengaruh terhadap harga lelang gula petani dalam jangka pendek, dimana pengaruh tersebut masih lebih kecil dibandingkan isu kebijakan penerapan PPN. Dalam jangka panjang, kebijakan HAP dan isu penerapan PPn tidak secara signifikan berpengaruh terhadap harga lelang gula. Penetapan HAP sebesar Rp 12.500/kg memang memberi tekanan pada harga gula lelang petani. Akan tetapi, telah menurunkan margin ditingkat distributor namun harga lelang yang ada masih memberi keuntungan yang memadai kepada petani. Terdapat faktor lain yang menyebabkan rendahnya harga lelang gula ditingkat petani yaitu adanya satgas pangan serta harga gula impor yang rendah. Harga gula impor yang rendah berdampak pada potensi 
rembesan gula kristal rafinasi (GKR) ke pasar konsumen.

Rekomendasi kebijakan yang dapat disampaikan, yaitu (a) kebijakan HAP, tidak menjadi faktor penyebab rendahnya harga gula di tingkat petani. Dengan demikian, penetapan kebijakan HAP pada komoditi gula dapat terus dilakukan dalam rangka stabilisasi harga dengan melakukan evaluasi secara berkala, (b) pemerintah dapat mempertahankan HAP gula sebesar Rp $12.500 / \mathrm{kg}$ yang didukung oleh beberapa hal yaitu: (i) penangguhan penerapan PPN gula petani. Dalam hal ini, perlu koordinasi antara pemerintah terkait untuk memastikan bahwa pedagang atau distributor GKP tidak memanfaatkan isu PPN gula dengan menekan harga gula di tingkat petani; (ii) mengevaluasi adanya satgas pangan yang memberikan sanksi terkait dengan penjualan gula di atas HAP dan penimbunan, serta (iii) menerapkan pengawasan pasar gula yang memberikan kepastian pada petani, pabrik gula, dan konsumen yang mengacu kepada Peraturan Menteri Perdagangan Nomor 117/MDAG/PER/12/2015 tentang Ketentuan Impor Gula yang dapat selaras dengan peraturan lainnya di bidang perlindungan konsumen dan perdagangan gula rafinasi. Dalam jangka panjang, optimalisasi Peraturan Menteri Perdagangan Nomor 20/MDAG/PER/3/2017 Tentang Pendaftaran Pelaku Usaha Distribusi Barang Kebutuhan Pokok perlu dipertahankan. Hal ini menjadi penting karena transparansi pengelolaan stok oleh pelaku usaha distribusi dapat lebih efektif sehingga tindakan dalam rangka pencegahan moral hazard seperti penimbunan dan spekulasi dapat lebih efektif karena berdasarkan laporan perkembangan stok, Dengan demikian, pemerintah dapat melakukan penilaian apakah pengelolaan stok telah dilakukan sesuai ketentuan atau tidak.

\section{UCAPAN TERIMA KASIH}

Ucapan terima kasih disampaikan kepada Pusat Pengkajian Perdagangan Dalam Negeri yang telah memberikan dukungan dalam pelaksanaan analisis ini serta semua Tim.

\section{DAFTAR PUSTAKA}

Angelo, A. and Zapata, H. (2000). Further Empirical Evidence of Wheat and Barley Market Integration in the EU. Department ofAgricultural Economics. Lousiana State University

Akanni.K.A. (2013). Agricultural Price Policy, Cunsumer Demand and Implications for Household Fodd Security in Nigeria. International Journal of Food and Agricultural Economics, Vol 2 (1), 121 - 132. 
BPS. (2017). Laporan Data Sosial Ekonomi. Terbit bulanan. Badan Pusat Statistik. Jakarta.

BPS. (2016). Laporan Data Sosial Ekonomi. Terbit bulanan. Badan Pusat Statistik. Jakarta.

Cahyaningsih, E. (2015). Analisis Integrasi Pasar Gula Dalam Mendukung Stabilitas Harga Gula. Jurnal Pangan, Vol 24 (2).pp: 83-96.

Chicago Board of Trade (CBOT). (2017). White sugar-raw Sugar prices. Barchart Technical-chart.

https://www.barchart.com/futures/quote s/technical-chart.

Dewan Gula Indonesia (DGI). (2017). Perkembangan Harga Lelang Gula. Kementerian Pertanian. Jakarta.

Engle, R and Granger, C. (1987). "Cointegration and Error Correction Representation, Testing and Telling" Econometrica 55(2), pp: 251-276.

Ernawati, L dan Erna, S. (2013). Analisis Faktor Produktivitas Gula Nasional dan Pengaruhnya Terhadap Harga Gula Domestik dan Permintaan Gula Impor dengan Menggunakan Sistem Dinamik. Jurnal Teknis Pomits, Vol 1 (1).pp: 1-7.

Galtier, F. (2013). Managing Food Price Instability. Critical Assesment of The Dominant Doctrine. Global Food Security 2.pp.72-81.

Hairani RI, JMM Aji, dan J.Januar. (2014). Analisis Trend Produksi dan Impor Gula serta Faktor-faktor yang mempengaruhi impor gula Indonesia. Jurnal Berkala IImiah Pertanian Vo 1 (4).pp: 77-85.

Haryana, A. \& Wicaksena, B. (2016). Gula Rafinasi vs Gula Rakyat di Pasar Konsumen. Media Pusdiklat, Vol 5 (3).pp: 33-38.

Kornher, L \& Kalkuhl, M. (2013). Food Price Volatility in developing Countries and Its Determinants. Quarterly Journal of International Agriculture. Vol 52(4): 277-
308. Diunduh tanggal 10 Juli 2018 dari http:

http://ageconsearch.umn.edu/bitstream /156132/2/B4-Kornher-Food_c.pdf.

KPPU. (2010). Posisition Paper: Komisi Pengawas Persaingan Usaha Terhadap Kebijakan Dalam Industri Gula. Posisition Paper. Jakarta.

McKay, A. (1998). Aggregate Export and Food Crop Supply Response in Tanzania. DFID-TERP: Credit Discussion Paper 4 (CDPO4). University of Nottingham.

Nugraheni, W.S.R. (2014). Volatilitas Harga Pangan Utama Indonesia dan Faktor yang Mempengaruhinya. Thesis Pasca Sarjana IPB, Bogor.

Pesaran, H. M. and Pesaran, B. (1997) Microfit 4.0 (Oxford University Press).

Pusat Kebijakan Perdagangan Dalam Negeri (Puska Dagri). (2015). Analisis Lelang Gula PTPN/Petani Dalam Rangka Stabilisasi Harga. Laporan Akhir Kajian. Badan Pengkajian dan Pengembangan Perdagangan. Kementerian Perdagangan. Jakarta.

Rahayuningrum, N. dan Lubis, A. (2006). Kajian Kebijakan Gula: Faktor-faktor yang mempengaruhi harga eceran gula. Badan Penelitian dan Pengembangan Perdagangan. Jakarta

Rahman, Z. (2015). Problematika Penegakan Hukum Terhadap Pelaku Tindak Pidana Penimbunan Pangan. Jurnal Rechts Vinding. Jakarta.

Sa'diyah, C; AW.Muhaimin; dan Suhartini. (2014). Faktor-faktor yang mempengaruhi kinerja ekonomi gula nasional di Indonesia. Jurnal Habitat. Vol. 25 (2).pp: 70-77.

Sistem Pemantauan Pasar Kebutuhan Pokok (SP2KP). (2017).Harga Pangan Pokok. Ews.kemendag.go.id. Kementerian Perdagangan. Jakarta 
Susila, W.R dan Bonar M. Sinaga. (2005). Analisis Kebijakan Industri Gula Indonesia. Jurnal Agro Ekonomi. Volume 23 No 1. Pp: 30-53.

Susila, W.R dan E. Munadi. (2008). Analisis Keterkaitan Harga Gula Eceran, Sistem Distribusi dan Laju Inflasi. Informatika Pertanian, Vol 17 (1), pp:1085-1103. Jakarta.

Wicaksena, B. (2017). Analisis Rentang Harga Gula Kristal Rafinasi Pada Pasar
Lelang Komoditas Dengan Pendekatan Paritas. Jurnal Borneo Administrator Vol 13( 2), pp. 169-183.

Yunitasari, D; D.B Hakim; B. Juanda; dan R.Nurmalina. (2015). Menuju Swasembada Gula Nasional: Model Kebijakan untuk meningkatkan produksi gula dan pendapatan petani tebu di Jawa Timur. Jurnal Ekonomi \& Kebijakan Publik. Vol 6 (1).pp: 1-15. 
